\title{
Influence of Work Discipline, Career Development and Job Satisfaction on Employee Performance Directorate General Research and Development of Ministry Research, Technology and Higher Education
}

\author{
Cedaryana $^{1}$, Muchlis R. Luddin ${ }^{2}$, Yetti Supriyati ${ }^{3}$ \\ ${ }^{1}$ Doctoral Program, Human Resource Management, Jakarta State University \\ And Directorate of Research and Community Service \\ ${ }^{2}$ Lecturer, Jakarta State University, Indonesia \\ ${ }^{3}$ Lecturer, Jakarta State University, Indonesia
}

\begin{abstract}
This causal research aims to find out information about possible employee performance that is influenced by work discipline, career development, and job satisfaction. The survey method used in this study is data that has been analyzed by path analysis after all variables are incorporated into the correlation matrix. Data were collected from 113 employees as randomly selected samples. The result of the research found that: (1) work discipline has a positive effect on employee performance, (2) career development have positive effect on employee performance, (3) job satisfaction have positive effect to employee's performance, (4) work discipline has positive effect to job satisfaction, 5) career development has a positive effect on job satisfaction, and (6) work discipline has a positive effect on career development. The results showed that work discipline, career development, and job satisfaction are the determinants of employee performance.
\end{abstract}

Keywords: Employee Performance, Work Discipline, Career Development, and Job satisfaction.

\section{Introduction}

The Directorate General for Research and Development at the Ministry of Research, Technology and Higher Education is a new Directorate that has existed since January 2015 which oversees the Directorate of Research and Community Service of the Directorate of Higher Education (formerly). And from that moment the Directorate General of Higher Education is no longer under the Ministry of Education and Culture.

The Directorate General for Research and Development has a secretariat of Directorate General and 4 (four) Directorate General: Directorate of Research and Community Service, Directorate of Intellectual Property Rights, Directorate of Industrial Technology Development and Directorate of Research and Development System. Each Directorate General has 4 (four) Sub Directorates.

In today's era of globalization, excellent human resources are essential to carry out office tasks. An employee is expected to have high skill and dedication. Superior human resources in an office are necessary and to get it all requires training and courses. Employees as human resources should be empowered through good human resource management.

The performance of an officer of the state apparatus refers to a clear and measurable indicator, through the SKP format (employee work target) for each work unit, where the job description is described, the output of both quality and quantity and time targets to be completed on the job and the quantity cost. Based on the report or performance data of employees of Directorate General of Research and Technology Kemenristekdikti, showing results that have not been satisfactory, meaning that the performance of 
employees have not reached the target in accordance with the standards specified, for example when monitoring and evaluation in the field of research capacity improvement for pengigkatan qualifications, , But in reality the time provided is not sufficient and exceeded the time provided, other things that show less than maximum performance on the Directorate General of Research and Technology Kemenristekdikti such as preparing programs to increase the capacity of research to increase qualifications by making 5 pieces of fact reports only reached 4 pieces Report, this is the reason the author to do research, because there are still problems that need to be further research.

Without good employee discipline, it is difficult for the organization to achieve optimal results. Employee discipline can be seen from the presence of employees every day, the accuracy of working hours, wearing work clothes and identification, and obedience of employees to the regulations. Employee discipline at the Directorate General of Research and Technology Kemenristekdikti showed less maximal discipline such as the presence of less than the maximum, meaning that if diprosentasekan not yet reached $100 \%$.

Discipline is a form of obedience or obedience to government rules or regulations or ethics, norms, and rules applicable in society. Obedience or obedience is done by humans in a society within a country. A group of people who do discipline in all things in their life will create a disciplined society, as well as a disciplined society will manifest a disciplined country.

Discipline is often used as a tool in an organization to realize the goals of the organization. No exception in government organizations especially government apparatus (PNS) whose purpose is to serve the public as well as possible.

Civil Servants (PNS) both as individuals in a society and as members in a government organization, not apart from the provisions of existing regulations. Norms, rules of society, rules, codes of ethics in government organizations must be obeyed and obeyed. Compliance and obedience is a form of employee discipline against the provisions that govern the relationship between people and people and people with government organizations.

Productive patterns and work ethic affect the performance in serving the public, so that the public will be satisfied with services provided by these employees.

The reason of the writer to choose the research place at Directorate General of Research and Technology Development of Higher Research, Technology and Higher Education, because still not yet reach the target for employee performance level, both in Employee Work Target and in Performance Value like 2016 data is SKP $92 \times 60 \%=55.20 \%$ The value of work and attendance behavior $94.33 \times 40 \%=37.73 \%$ total $92.93 \%$. Other things such as career development, there are still employees with rank / class IVa, still a regular employee, or employees who do not have a position in the workplace, this means that ladder and career development has not been implemented optimally.

With the problem it needs a way to improve employee performance that is influenced by many factors among them; Discipline of work, job satisfaction, career development of employees and the level of education associated with the competence of employees. The. In addition, there are still negative factors that degrade performance.

Based on the description on the background of the problem, the author's interest to examine further with the title: "The Effect of Work Discipline, Career Development and Job satisfaction on Employee Performance at the Directorate General of Research and Development of the Ministry of Research, Technology and Higher Education"

With the problem it needs a way to improve employee performance that is influenced by many factors among them; Discipline of work, job satisfaction, career development of employees and the level of education associated with the competence of the employee. In addition, there are still negative factors that degrade performance. 


\section{Literature Review}

Achieving the performance that has been achieved and referring to the action of achievement and the execution of any work requested. This is in accordance with the opinion of Rivai (2008: 309) stating that the performance is "the real behavior that is displayed every person as work performance generated by employees in accordance with its role in the company." Behavior in question is the output or output results obtained by employees In performing their duties. Wibowo (2014) states performance is about doing the job and the results achieved from the job. And performance is about what to do and how to do it. The above quotation can be understood that the performance is more emphasis on the results or something that is obtained from a job as a contribution to the work unit. Therefore the person who wishes to achieve his performance increases is the person who works based on the elements above and in carrying out their duties done seriously.

Achievement of organizational goals can be known success rate through evaluation or assessment, both individual assessment and group assessment. Evaluating a person's performance can not be separated from the assessment of the good performance of the person. Performance evaluation is a performance appraisal compared to a plan or standards agreed upon at a given time. To evaluate one's performance is to judge a person's overall performance over a given period.

The system of performance appraisal of civil servants who are open, is expected to increase the motivation and productivity of work and create the relationship of interaction between appraisal officials with civil servants assessed in order objectivity assessment and to get job satisfaction every civil servant.

Performance of employees in this study is the work achieved by employees within a certain period of time supported by the skills, expertise and skills of employees that can be measured through indicators; (1) work processes and conditions of employment, (2) time of carrying out work, (3) job accuracy and quality of work, (4) skill level in work and (5) ability to evaluate.

\section{Work Discipline}

Discipline is the attitude, behavior and deeds, what in accordance with the rules of the company both written or that is unwritten. The regulation is including absentee, lately coming and get home fast. So this is an indiscipline attitude of employees that needs to be addressed properly by the management. Discipline is one of the requirements of employees to meet the standards of performance and behavior, including maintaining the presence of employees according to predefined time standards

Discipline is the attitude, behavior and deeds in accordance with company regulations both written and unwritten. The rules include absenteeism, slow entry and fast return. So this is an employee's disciplinary attitude that needs to be addressed properly by the management. Discipline is one of the requirements of employees to meet the standards of performance and behavior, including maintaining the presence of employees according to predefined time standards.

Work discipline is needed by every employee. Discipline becomes a prerequisite for the formation of attitudes, behaviors, and discipline of disciplined life that will make the employees get ease in working. That way will create a conducive working atmosphere and support efforts to achieve goals.

Based on the above description of the concept can be concluded that the discipline of employee work in this study is the awareness and willingness of employees to obey the rules of the organization both written and unwritten and not evasive to receive sanctions if violating the duties and authority given to him, which can be measured Through indicators: (1) compliance with organizational rules, (2) organization fair to all employees, (3) supervision carried out at any time, (4) penalty sanction and (5) Have job responsibilities

\section{Career Development}

Career development is a way for organizations to maintain or improve employee productivity, and prepare employees for future careers. Thus it can be understood that the career development of employees need to be 
planned by the organization, so that employees have the quality as desired by the organization with the standard set of performance standards.

Employee career development in this research is a formal and continuous effort with focus on increasing and adding ability, skill and expertise of an employee so that change of values, attitudes and motivation can be measured through indicator; (1) formulate work plan, (2) follow training, (3) solve problems, (4) placement of staff, and (5) able to communicate.

\section{Job satisfaction}

In general productivity is defined as the relationship between the output (output) generated with the input (input) is the truth. Job satisfaction as a concept that shows the relationship between the output (the work) with the time required to produce the product of a workforce. Sinungan (2009: 12) states that productivity is an indiscipline approach to determine the effective goal of making plans, the application of the use of a productive way to use resources efficiently but still maintain a high quality. The two quotations above basically emphasize that productivity is the result obtained by employees by comparing the inputs of employees, with the implementation effectively and efficiently.

According to Wibowo (2014) the productivity of an activity is said to increase if the program development provides additional results as a by product or by product. Furthermore Wibowo (2014) states an organization is said to be productive when it reaches its goal and it happens by converting input into output at the lowest cost. Productivity is a measure of performance, including effectiveness and efficiency. Siagian (2009) states job satisfaction is the ability to obtain the maximum benefit from available facilities and infrastructure by producing optimal output, if possible the maximum. According to Mathis and Jackson (2011) that productivity is a measure of the quantity and quality of work done, considering the cost of the resources used. (Productivity is a measure of quantity and quality of work done, given the cost of resources used).

According Sinungan (2009) high low productivity of one's work is influenced by several factors, namely:

1. human

2. capital

3. Method (process)

4. Organizational environment (internal)

5. Production environment

6. Country environment (external)

7. Internal and regional environment

8. Feedback

According Sutrisno (2010) factors that affect job satisfaction are: (1) Training, (2) Mental and physical skills of employees, (3) The relationship between superiors and subordinates. The quotation means that the productivity of work will be maximally achieved if supported by the ability of employees through training, physical ability and most importantly a harmonious communication either leadership with bwahan or between employees with employees.

Simamora (2014) states that the factors used in the measurement of labor productivity include:

1. Quantity of work is a result achieved by employees in a certain amount with a comparison of standards set by the company.

2. Quality of work is a result standard relating to the quality of a product produced by employees.

3. Timeliness is the level of an activity completed at the beginning of a given time.

Based on the above description can be concluded that the meaning of employee productivity in this study is the work done by employees exceeding the target that has been determined, so that the achievement of the 
goals that have been outlined reached the maximum, which can be dikur through indicators; (1) employee attendance, (2) timeliness, (3) outputs generated, (4) superior and subordinate relationships, and (5) reward systems.

Based on the literature reviewed, the following hypotheses were formulated :

$\mathrm{H}_{1}$. There is a direct positive influence of work discipline on employee performance

$\mathrm{H}_{2}$. There is a positive direct effect of career development on employee performance

$\mathrm{H}_{3}$. There is a direct positive effect of job satisfaction on employee performance

$\mathrm{H}_{4}$. There is a positive direct effect of work discipline on job satisfaction

$\mathrm{H}_{5}$. There is a positive direct effect of career development on job satisfaction

$\mathrm{H}_{6}$. There is a positive direct effect of work discipline on career development

\section{Conceptual Framework}

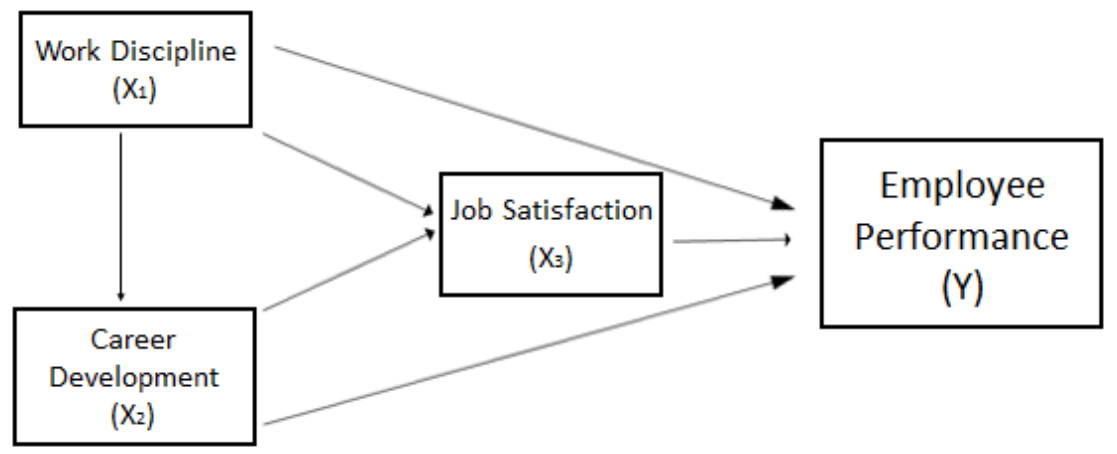

\section{Research Methodology}

The method used in this research is a survey with causal analysis approach. In this causal approach the path analysis technique is used. This path analysis is used to examine the direct and indirect effects of the variables studied, namely: work dispilin, career development, and job satisfaction on employee performance Directorate General Research and Development Ministry of Research, Technology and Higher Education.

\section{Result}

Tabel 1.

Coefficient Sub- Structure1

\begin{tabular}{|c|c|c|c|c|c|}
\hline \multicolumn{6}{|c|}{ Coefficients" } \\
\hline \multirow[t]{2}{*}{ Model } & \multicolumn{2}{|c|}{ Unstandardized Coefficients } & \multirow{2}{*}{$\begin{array}{c}\text { Standardized } \\
\text { Coefficients } \\
\text { Bets }\end{array}$} & \multirow[t]{2}{*}{$t$} & \multirow[t]{2}{*}{ Sig. } \\
\hline & $\mathrm{B}$ & Std. Error & & & \\
\hline (Constant) & 28.516 & 5.010 & & 5.692 & .000 \\
\hline$\times 3$ & .349 & .099 & .390 & 3.508 & .001 \\
\hline$\times 2$ & -159 & .090 & .179 & 2.763 & .081 \\
\hline$\times 1$ & .277 & .077 & .317 & 3.617 & .000 \\
\hline
\end{tabular}

a. Dependent Variable: Y

Substructure model 1 
Based on the result of SPSS version 20.0 analysis obtained path coefficient as follows:

1. Py1 of $0.317 ; \mathrm{t}_{\text {hitung }}=3,617$ and p-value $=0.000 / 2=0,000<0,05$ or $\mathrm{H} 0$ is rejected, which means there is influence of work discipline (X1) to employee performance variable (Y).

2. Py 2 of $0.179 ; \mathrm{t}_{\text {hitung }}=2,763$ and $\mathrm{p}$-value $=0,081 / 2=0,041<0,05$ or $\mathrm{H} 0$ is rejected, which means there is influence of career development (X2) on employee performance variable (Y).

3. Py3 of $0.390 ; \mathrm{t}_{\text {hitung }}=3.508$ and $\mathrm{p}$-value $=0.001 / 2=0,000<0.05$ or $\mathrm{H} 0$ is rejected, which means there is influence of job satisfaction (X3) on employee performance variable (Y).

Tabel 2.

Coefficient Sub- Structure2

\begin{tabular}{|c|c|c|c|c|c|c|}
\hline \multicolumn{7}{|c|}{ Coefficients $^{2}$} \\
\hline \multicolumn{2}{|c|}{ Model } & \multicolumn{2}{|c|}{ Unstandardized Coefficients } & \multirow{2}{*}{$\begin{array}{c}\text { Standardized } \\
\text { Coefficients } \\
\text { Bets }\end{array}$} & \multirow[t]{2}{*}{$t$} & \multirow[t]{2}{*}{ Sig. } \\
\hline & & B & Std. Error & & & \\
\hline \multirow{3}{*}{1} & (Constant) & 1.989 & 4.803 & & .414 & .679 \\
\hline & $x_{1}$ & .344 & .066 & .352 & 5.242 & .000 \\
\hline & $x_{2}$ & .581 & .067 & .583 & 8.688 & .000 \\
\hline
\end{tabular}

a. Dependent Variable: X3

Substructure model 2

Based on the result of SPSS version 20.0 analysis obtained path coefficient as follows:

1. P31 of 0.352 ; Thitung $=5,242$ and p-value $=0,000 / 2=0,000<0,05$ or H0 is rejected, which means there is influence of work discipline (X1) to job satisfaction variable (X3).

2. P32 of 0.583; Thitung $=8,688$ and $\mathrm{p}$-value $=0.000 / 2=0,000<0,05$ or $\mathrm{H} 0$ is rejected, which means there is influence of career development (X2) on job satisfaction variable (X3).

Tabel 3.

Coefficient Sub- Structure3

\begin{tabular}{|c|c|c|c|c|c|c|}
\hline \multicolumn{7}{|c|}{ Coefficients $^{2}$} \\
\hline \multirow{2}{*}{\multicolumn{2}{|c|}{ Model }} & \multicolumn{2}{|c|}{$\begin{array}{l}\text { Unstandardized } \\
\text { Coefficients }\end{array}$} & \multirow{2}{*}{$\begin{array}{c}\text { Standardized } \\
\text { Coefficients } \\
\text { Bets }\end{array}$} & \multirow[t]{2}{*}{$t$} & \multirow[t]{2}{*}{ Sig. } \\
\hline & & $B$ & Std. Error & & & \\
\hline \multirow{2}{*}{1} & (Constant) & 32.733 & 6.071 & & 5.392 & .000 \\
\hline & $x_{1}$ & .704 & .065 & .717 & 10.829 & .000 \\
\hline
\end{tabular}

Substructure model 3

Based on result of SPSS version 20.0 analysis obtained path coefficient as follows P21 equal to 0,717 ; Thitung $=10,829$ and $\mathrm{p}$-value $=0,000 / 2=0,000<0,05$ or $\mathrm{H} 0$ is rejected, which means there is influence of work discipline (X1) to career development variable (X2).

Structure a diagram of a whole of a track any structure is presented in this figure: 


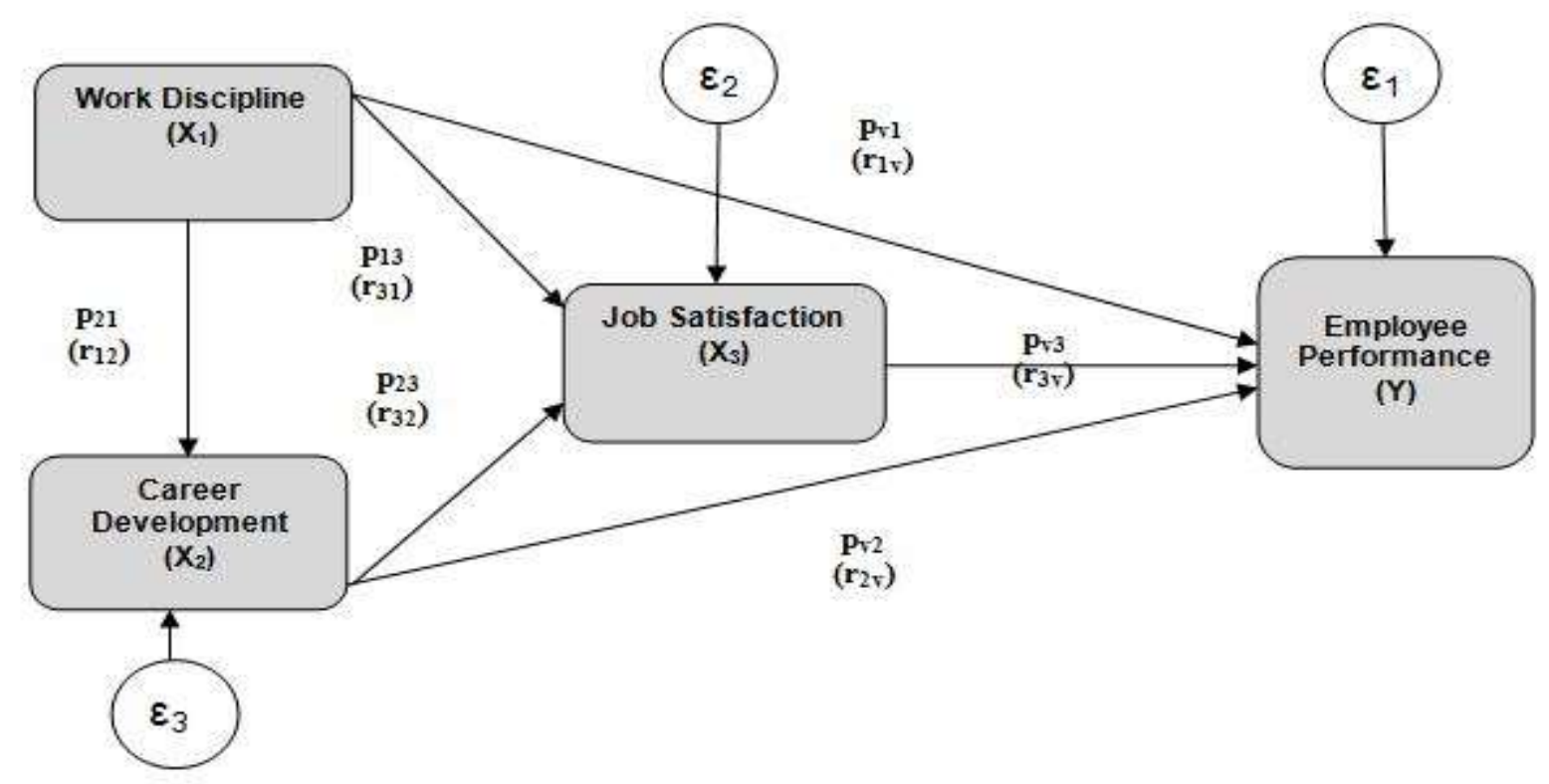

A Diagram Causal Influence $X_{1}, X_{2}$ and $X_{3}$ to $Y$

\section{Discussion}

Based on the analysis and the hypotheses shows that sixth hypothesis advanced by the research was generally proved every lines has a direct positive effect. In detail, the analysis and the testing of hypotheses research is described as follows:

\section{Influence Work Discipline to Employee Performance}

The work discipline direct positive effect to employee performance. The results of this temuain affirm that discipline is very important for the development of the organization, especially to motivate employees to discipline themselves in carrying out the work both individually and in groups, in addition to the discipline useful to educate employees to comply and enjoy the rules, procedures, and policies that exist, Can produce good performance.

Luthan (2009) states that In behavioral management, discipline should attempt to be a learning experience, never purely a coercive experience to prove mastery or control over others. The quotation can be interpreted that by menyipiln through learning experience, hence expected organizational goal that hopefully can be realized, because someone who discipline will obey the rules set by organization.

\section{Influence Career Development to Employee Performance}

The career development direct positive effect to employee performance. These findings confirm that career development as an HR management activity is basically aimed at improving and improving the effectiveness of work implementation by workers, in order to be able to give the best contribution in realizing organizational goals. Career development is very important for an organization, because a career is a necessity that must be developed in an employee so as to motivate employees to improve its performance Mihai Jigău (2007) reveals that Career development is a lifelong process, a succession of choices; These are the same as work environment (economic, social, technological progress).

The quotation can be interpreted that career development is a lifelong process, in which changes arise both at personal or individual level (due to education, training, experience, access to new information), and environmental influences (economic, social, technological progress). In other words that an employee will be able to improve his career through individual effort and environmental influences. 
Research conducted by Neelam Tahir and Israr Khan Yousafzai concluded that: This paper is the main objective to investigate whether training and development has impact on employees' performance and productivity. (The results above confirm that training and development impact on employee performance and productivity).

\section{Influence Job satisfaction to Employee Performance}

The job satisfaction direct positive effect to employee performance. These findings confirm that job satisfaction is a component that can determine the main requirements in the success of a company. Productivity shows the level of quality of the company in the face of the era of competition so that companies can achieve goals that have been determined. This is similar to that proposed by Mathis and Jackson (2011: 9) that productivity is a measure of the quantity and quality of work done, considering the cost of the resources used. (Productivity is a measure of quantity and quality of work done, given the cost of resources used), the quote means that the success rate of job satisfaction by looking at the work both in quality and quantity.

Increased productivity is the desire of every company, productivity with regard to business or human activities to produce goods or services that are useful to meet the needs of human life and society in general. Torrington (2008) states that to develop high productivity by concentrating on the individual worker and the surrounding social relationships in the workplace, rather than adapting the worker to the task.

The above quote confirms that to develop high productivity by concentrating on the welfare of individual workers and establishing social relationships in the workplace, with an emphasis to adapt tasks to workers rather than adapt workers to tasks.

According to Greer (2001) "a worker's productivity is determined by the capital intensity of the job; Type and extension of on-the-job training provided; The worker's ability to learn from the training, which is signaled by education ". (Worker productivity is determined by the intensity of working capital, the type and level of on-the-job training available, the ability of workers to learn from training, which is characterized by education), the quotation can be interpreted that productivity is determined not only by achieving the desired target, Determined by the ability of employees such as training and education that followed.

\section{Influence of Work Discipline to Job satisfaction}

The work discipline direct positive to job satisfaction. These findings confirm that work discipline is an activity undertaken by employee attitudes and behaviors to obey, obey and respect and respect the prevailing stipulations both written and unwritten and able to accept sanctions for violations committed. Discipline is a very important thing in order to create qualified employees to perform the tasks assigned to him for the achievement of organizational goals, with discipline, it will manifest an attitude that reflects the obedience to any existing rules.

According to Byars-Rue (2004) that the discipline should be viewed as a learning opportunity for the employee and as a tool to improve productivity and human relations. (Discipline should be seen as learning opportunities for employees and as a tool to increase productivity and its relationship with humans), the quote means that employees who have a high discipline of the learning process will be easy to increase job satisfaction.

\section{Influence Career Development to Job satisfaction}

The career development direct positive to job satisfaction. These findings confirm that career development for employees is a process of learning and practicing systematically to improve their skills, skills, skills and performance in current work and prepare for future roles and responsibilities. This is similar as presented by Rivai (2008) that career development is the process of enhancing individual work ability achieved in order to achieve a desired career. According Mangkunegara (2015) that career development is a staffing activity 
that helps employees plan their future careers in the company so that the company and employees concerned can develop themselves to the maximum.

According to Zunker (2006) Career development is viewed as a lifelong process that is very inclusive. One major concept of developmental theories suggests that individuals make changes during developmental stages and adapt to changing life roles.

The quotation can be interpreted that career development is seen as a very inclusive lifelong process. One great concept of developmental theory suggests that individuals make changes during the developmental stage and adapt to changes in the role of life.

\section{Influence of Work Discipline to Career Development}

The work discipline direct positive to career development. These findings confirm that the discipline of work means the willingness of a person to arise with his own consciousness to follow the rules applicable in the organization, the discipline of work is also one of the requirements of employees to meet work standards and work behavior, including maintaining the presence of employees according to the time standard that has been Set.

According to Torrington (2008). Discipline is regulation of human activity to produce a controlled performance. It ranges from the guard's control of a rabble to the accomplishment of the lone- ers of its own talent and resources.

The above quotation may mean that discipline is the regulation of human activity to produce a controlled performance, which means the journey of the organization will be good, if the discipline in organization is obeyed by the members of the organization, to obtain high discipline results as expected, then a leader in his business Need to use certain guidelines or rules as the basis for the implementation of the discipline itself.

\section{Conclusion}

The conclusion of this research shows that there is direct positive influence of work discipline, employee performance, career development. There is a direct positive influence of work discipline to employee performance, career development to employee performance, job satisfaction is a direct influence to employee performance, career development is a direct influence to the employee performance, work discipline is a direct influence to the career development, job satisfaction is a direct influence to the work discipline, work discipline is a direct influence to career development.

\section{Reference}

[1] Alexander, Mark, Employee Performance and Discipline Problems: A New Approach, (anada: Industrial Relations Centre Printed and bound, 2009.

[2] Anderson, Neil, Deniz S. Ones, Handan Kepir Sinangil, Handbook of Industrial: Work and Organization Psychology Vol. 2. London: Sage Publications Ltd. 2001.

[3] Armstrong, Michael, Performance Management. India: Kogan Page, 2007.

[4] Byars-Rue, Human Resource Management. New York: McGraw-Hill Companies, 2004.

[5] Corrie, Sarah, Nicola Hurton and David A. Lane, How to Develop Your Career and Organise Your Contuining Professional Development. New York: Palmer The Practitioner's Handbook, 2007.

[6] Dessler, Garry, Manajemen Sumber Daya Manusia. Edisi Kesepuluh Jilid 1. Jakarta: Indeks. 2010.

[7] Garner, Eric, Effective Discipline How to Manage Discipline at Work. New York: Eric Garner \& Ventus Publishing Aps, 2012.

[8] George, Jennifer M., Gareth Jones, Understanding and Managing Organizational Behaviorhal. New York: Prentice Hall, 2012.

[9] Greer, Charles R., Strategic Human Resource Management. New Jersey: Prentice-Hall, Inc., 2001.

[10] Jigău, Mihai, Career Counselling Compendium of Methods and Techniques, Bucharest: AFIR, 2007. 
[11] Fred Luthans, Organizational Behavior. 12 ${ }^{\text {th }}$ Edition, New York: McGraw-Hill, Inc, 2009.

[12] Mangkunegara, A.A. Anwar Prabu, Manajemen Sumber Daya Manusia Perusahaan, (Bandung: PT. Remaja Rosdakarya, 2015.

[13] Evaluasi Kinerja Sumber Daya Manusia. Bandung: Refika Aditama. 2010.

[14] Mathis, Robert L. John H. Jackson, Human Resource Management. New York: South-Western, Cengage Learning, 2011.

[15] Nawawi, Hadar, Manajemen Sumber Daya Manusia. Yogyakarta: Gadjah Mada University Press. 2011.

[16] Peraturan Menteri Pendidikan dan Kebudayaan Nomor 16 Tahun 2012 tentang Kode Etik di Lingkungan Departemen Pendidikan dan Kebuayaan. (Jakarta: Kemendikbud. 2012).

[17] Peraturan Pemerintah Nomor 53 Tahun 2010. Tentang Disiplin Pegawai Negeri

[18] Permendagri. Peraturan Pemerintah Nomor 53 Tahun 2010. Tentang Disiplin Pegawai Negeri. Nomor 59 Tahun 2008 tentang Disiplin Jam kerja di Lingkungan Depdagri, pasal 2 ayat 1

[19] Phusavat, Kongkiti, Productivity Management in an Organization: Measurement and Analysis. Bangkok: ToKnow Press, 2013.

[20] Rivai, Veithzal dan Ahmad Fawzi Mohd. Basri, Performance Appraisal. Jakarta: Rajawali Pres. 2011.

[21] Rivai, Veithzal, Manajemen SDM untuk Perusahaan. Jakarta: Raja Grafindo Persada. 2008.

[22] Robbins, Stephen P., Organizational Behavior Concepts Controversies Applications. New York: Prentice Hall Published.

[23] Sedarmayanti, Manajemen Sumber Daya Manusia. Bandung: Refika Aditama. 2010.

[24] Siagian, Sondang P., Kiat Meningkatkan Produktivitas Kerja. Jakarta: Rineka Cipta. 2009.

[25] Manajemen Sumber Daya Manusia. Jakarta: Bumi Aksara. 2010.

[26] Simamora, Henry, Manajemen Sumber Daya Manusia. Yogyakarta: STIE YKPN. 2014.

[27] Sinungan, Muchdarsyah, Produktivitas. Jakarta: Bumi Aksara. 2009.

[28] .Sonnentag, Sabine and Michael Frese, Performance Concepts and Performance Theory. German: John Wiley \& Sons, Ltd. 2002.

[29] Sutrisno, Edy, Budaya Organisasi. Jakarta: Kencana, 2010.

[30] Manajemen Sumber Daya Manusia. Jakarta: Kencana. 2010.

[31] Torrington, Dereek, Laura Hall, Stephen Taylor, Human Resources Management. New York: Prentice Hall Ninth Edition Published, 2014.

[32] Umar, Husein, Evaluasi Kinerja Perusahaan. Jakarta: Gramedia Pustaka. 2005.

[33] Wibowo, Manajemen Kinerja. Jakarta: Raja Grafindo Persada. 2014.

[34] Widodo, Suparno Eko, Manajemen Pengembangan SDM. Yogyakarta: Pustaka Pelajar, 2015.

[35] Williams, Anne H., How to Discipline \& Document Employee Behavior, Tennessee: M. Lee Smith Publishers Llc, 2002.

[36] 33.Zunker, Vernon G, Career Counseling: A holistic Approach, 7th edition. Belmont CA: Thomson Brooks-Cole, 2006. 